\title{
Powerful not Poor: Reading Fanny Price from a Buddhist Perspective (Article)
}

\section{KATHRYN DUNCAN \\ St. Leo University}

$M$

ansfield Park is a novel about selfishness with characters who care more about the comfort of their own worldview than about anyone else. ${ }^{1}$ The characters are trapped by their chosen perspectives: Mrs. Norris by self-importance; Lady Bertram by indolence; Julia, Maria, and Mary by the desire to attract male attention; Tom by privilege; Sir Thomas by status; and Henry by seductive power. Even Edmund loses his way in his lust for Mary Crawford. Caught by these perspectives, the characters lack the freedom to live full, happy lives. Choosing worldviews intended to fend off suffering, the characters of Mansfield Park bring more suffering to themselves and others. Only Fanny, who materially suffers from the start and outwardly lacks freedom compared to the rest, lives mindfully and uses her powers to alleviate the suffering of others.

Fanny Price's reputation has suffered greatly among readers who have called her variously "poor Fanny," "prig," "monster," and more. ${ }^{2}$ While the name-calling may differ in criticisms of Fanny, complaints against her character generally refer to her dullness and her passivity. Lionel Trilling attributes to all detractors of Austen "the fear of imposed constraint," that is, the idea that society can or even should place limits upon the individual. Mansfield Park, according to Trilling, is the novel most guilty in Austen's canon of creating a sense of constraint and dullness: "No other great novel has so anxiously asserted the need to find security, to establish, in fixity and enclosure, a refuge from the dangers of openness and chance. There is scarcely one of our modern pieties that it does not offend." 3 These disparaging attitudes and offended "modern pieties" come from a Western mindset that values action and individualism. As Linda Troost and Sayre Greenfield note, a "cultural move toward active and outspoken women did not help the reputation of the physically weakest and quietest of Austen's heroines." ${ }^{4}$ In other words, like the characters of the novel, contemporary critics are trapped by a Western perspective that leads to the devaluing of one of Jane Austen's most enlightened characters.

Seeing Fanny from a different perspective, specifically an Eastern one, readers can appreciate that she has the traits of a bodhisattva, a figure devoted to enlightenment for the purpose of helping others. ${ }^{5}$ A bodhisattva is someone who consciously aspires to awaken bodhicitta, the "mind of love," defined by Buddhist monk Thich Nhat Hanh as the "deep wish

1. Amy J. Pawl argues that the "cardinal Austen sin [is] selfishness" (315) in "Fanny Price and the Sentimental Genealogy of Mansfield Park," Eighteenth-Century Fiction 16, no. 2 (2004), 287-315. Tony Tanner says of Mansfield Park that "it is a book about the difficulty of preserving true moral consciousness amid the selfish manoeuvring and jostling of society" (171) in Jane Austen (Cambridge: Harvard University Press, 1986).

2. Linda Troost and Sayre Greenfield's “A History of the Fanny Wars,” Persuasions 36 (2014), 15-33, best captures the many negative opinions of Fanny through careful documentation of reactions to her throughout the centuries.

3. Lionel Trilling, "Mansfield Park," in Jane Austen: A Collection of Critical Essays, ed. Ian Watt (Englewood Cliffs, NJ: Prentice-Hall, 1963), 124-40, 127.

4. Troost and Greenfield write that "admiring her was tantamount to endorsing behavior and sentiments seen as old fashioned and "Victorian"' (History of the Fanny Wars, 29).

5. In Jane Austen and the Theatre (Cambridge: Cambridge University Press, 2002), Penny Gay calls her a "true Christian heroine" (118). 
to cultivate understanding in ourselves in order to bring happiness to many beings." ${ }^{\prime 6}$ Doing so "means surrendering completely, with an attitude of letting whatever happens happen; if it's better for me to have pleasure, let me have pleasure; if it's better to have pain, let me have pain." While there are bodhisattvas that can be invoked to support enlightenment, anyone can aspire to be one, even poor Fanny. ${ }^{8}$

The Buddhist text elucidating what it means to be a bodhisattva was written by an eighth-century Indian prince-turned-monk named Shantideva, a name that translates to "God of Peace." The Way of the Bodhisattva is based upon a speech delivered by Shantideva at Nalanda University, the largest and most powerful Indian monastery at the time. The story goes that Shantideva was lazy, quite a terrible monk, and in order to either shame or motivate him to do better, the monks invited him to give a talk to the entire university - an honor usually only conferred on the best students, who sat on a throne while speaking. Ostensibly, the monks made the throne even higher than typical and provided no stairs, but Shantideva had no trouble mounting the throne and then delivered the entire text of The Way of the Bodhisattva. His speech is not remarkable for groundbreaking new ideas as much as for being poetic, personal, and, therefore, moving. As he concluded his talk with a discussion on the idea of emptiness, he began to float, eventually rising so high above the monks that they could not see him but could only hear his voice; he then disappeared. He spent the rest of his life as a wandering yogi.

I am not arguing that Austen knew anything about Buddhism, but there is overlap between Buddhist ideas about enlightenment and the British Enlightenment. As Peter KnoxShaw's work Jane Austen and the Enlightenment argues, Austen's novels embody the important ideas of the Enlightenment: science, reason, and social reform, as well as "an emphasis on the limits of individual heroism" and distrust of doctrine. ${ }^{9}$ The last two British Enlightenment qualities overlap with those from Buddhist enlightenment. Well before John Locke, the Buddha similarly privileged experience, explicitly acknowledging that his wisdom came from personal experience.

We need to remember that the Buddha was not a god but an individual. He began life as Siddhartha Gautama, an Indian prince whose father protected him from all suffering. Eventually, though, Siddhartha witnessed human suffering firsthand. He consequently renounced wealth and went in search of enlightenment, leaving the palace to join ascetics on his quest. After many years of difficult practice, the Buddha failed to achieve enlightenment. He left his fellow ascetics, eventually meditating under the Bodhi Tree, where he came to understand the origin and cure for suffering: the Four Noble Truths. The Buddha prefaced his first teaching by saying, "I tell you that if I have not experienced directly all that I have told you, I would not proclaim to you that I am a free person." ${ }^{10}$ Because each person has the Buddha within, that is, has the potential to achieve Buddhahood or enlightenment, Thich Nhat Hanh notes the importance of the primacy of personal experience in the creation of

6. Thich Nhat Hanh, The Heart of the Buddha's Teachings: Transforming Suffering into Peace, Joy, and Liberation (New York: Broadway Books, 1999), 62.

7. Pema Chodron, No Time to Lose: A Timely Guide to The Way of the Bodhisattva (Boulder, CO: Shambhala, 2017), 248.

8. An aspiring bodhisattva can invoke the "four great bodhisattvas-Avalokiteshvara (Regarder of the Cries of the World), Manjushri (Great Understanding), Samantabhadra (Universal Goodness), and Kshitigarbha (Earth Store)." Thich Nhat Hanh, "Dharma Talk: Cultivating our Bodhisattva Qualities," The Mindfulness Bell 22 (1998), https://www.mindfulnessbell.org/archive/2016/01/dharma-talk-cultivating-our-bodhisattva-qualities2?rq=dharma\%20talk\%20bodhisattva.

9. Peter Knox-Shaw, Jane Austen and the Enlightenment (Cambridge: Cambridge University Press, 2009), 5.

10. Thich Nhat Hanh, Heart of the Buddha's Teachings, 7. 
ideas: "When our beliefs are based on our own direct experience of reality and not on notions offered by others, no one can remove these beliefs from us." 11 Or as Fanny puts it in Mansfield Park, "We have all a better guide in ourselves, if we would attend to it, than any other person can be." 12 So Austen and Buddhism share an emphasis on a distrust of doctrine not tested by reason and experience.

The truth the Buddha discovered under the Bodhi Tree revolves around suffering. The Four Noble Truths state that suffering is inevitable, that we can and should discover the cause of our suffering, that we can end our suffering, and that the key to ending suffering is the Middle Way, or eightfold path: Right View, Right Thinking, Right Mindfulness, Right Speech, Right Action, Right Diligence, Right Concentration, and Right Livelihood. When the Buddha stated that suffering could be ended, he did not mean we could rid ourselves of all physical pain or prevent painful events, such as a family member's death. Rather, while difficulties are inevitable in life, the way we approach challenges can produce suffering or not. Alas, humans have a strong, mindless tendency to produce more suffering. As the translators of The Way of the Bodhisattva state, "If suffering is the fruit of thought and action, it can be avoided."13 Avoiding it means seeing the world correctly (Right View), not being trapped by concepts and not creating stories that produce harm to ourselves and others.

The key is stories - or narrative. As Zen teacher David Loy writes in The World Is Made of Stories, "Like the proverbial fish that cannot see the water they swim in, we do not notice the medium we dwell in. Unaware that our stories are stories, we experience them as the world." ${ }^{14}$ Humans constantly and consistently interpret phenomena and create narrative. For example, consider the physiological symptoms of anxiety and their relationship to storymaking and suffering. Alison Wood Brooks argues that telling ourselves to be calm when anxious about a performance does not work, but her experiments demonstrate that the physiological symptoms of anxiety are very similar to those of excitement. If, therefore, we choose to label the physical symptoms as excitement, we shift the narrative, making ourselves excited and ready to perform, freeing up working memory and allowing for a potentially better performance. Nothing has changed except for the explanation we offer ourselves - that is, the story. ${ }^{15}$ The problem is, as Pema Chodron puts it, that humans tend to get caught by and suffer from their own "very important stories." 16 In other words, we have a tendency to go with the story that will cause more suffering because we usually are unaware that we are engaged in narrative at all.

Our blindness to narrative and our construction of harmful stories often comes from being trapped by concepts and reacting habitually rather than seeing the present moment with freshness. All of the steps of the eightfold path begin with the word right, but right is defined contextually, not doctrinally. Connecting back to the primacy of experience, Thich Nhat Hanh explains, "Right and wrong are neither moral judgments nor arbitrary standards imposed from the outside. Through our own awareness, we discover what is beneficial ('right')." 17 This is why Buddhism is based in practice and requires presence and flexibility, which cannot happen when we are blocked by concepts - ideas about how things are or must

11. Thich Nhat Hanh, Living Buddha, Living Christ (New York: Riverhead Books, 2007), 220.

12. Jane Austen, Mansfield Park (New York: Oxford World's Classics, 2003), 342.

13. Shantideva, The Way of the Bodhisattva, ed. and trans. Padmakara Translation Group (Boston: Shambhala, 2006), 8.

14. David Loy, The World Is Made of Stories (Somerville, MA: Wisdom Publications, 2010), 19.

15. Alison Wood Brooks, "Get Excited: Reappraising Pre-Performance Anxiety as Excitement," Journal of Experimental Psychology 143, no. 3 (2014), 1144-158.

16. Pema Chodron, When Things Fall Apart: Heart Advice for Difficult Times (Boston: Shambhala, 2011), 114.

17. Thich Nhat Hanh, Heart of the Buddha's Teachings, 11. 
be. Pema Chodron, in her commentary on Shantideva's text, compares being trapped by concepts to a full pot with no room to add new ideas or opinions, a pot filled with poison where negativity prevents openness, or a pot with a hole in the bottom in which distraction with our own preconceptions prevents engagement with the present moment. A closed mind "that fixates, conceptualizes, and compartmentalizes; a mind incapable of seeing things without bias," leading to "false views," will create false narratives that lead to suffering rather than approaching each moment with a fresh perspective. ${ }^{18}$

To further complicate things, our narratives interact with the narratives of others; all choices are dynamic, with mine being affected by all those around me. As Douglas Kenrick et al. argue, "Not only does it take two to tango, but two rarely tango alone in a dark basement; instead, their carefully coordinated maneuvers are typically executed within a larger ballroom crowd who often change partners as they move in time to the same rhythms."19 This is why the role of the bodhisattva is so crucial. She has vowed to reach enlightenment in order to heal others to achieve freedom from damaging narratives, thereby eliminating suffering not only from her own life but from those around her.

No writer seems to have understood the connection of narrative to suffering so well as Austen. Her culture had a tightly woven but unraveling narrative about proper behavior for ladies and gentlemen, a code that could, for example, create great pride or prejudice. Her novels deal explicitly with the themes of false narratives driven by concepts and self-interest. $^{20}$

Certainly, this is the case in the Bertram household, in which, to give one example, Sir Thomas asks Maria if she really wishes to marry Mr. Rushworth after he discovers for himself that Rushworth is an "inferior young man, as ignorant in business as in books, with opinions in general unfixed, and without seeming much aware of it himself." ${ }^{21}$ Maria hesitates but responds with an immediate assertion of her willingness to continue the engagement, though the reader, unlike her father, understands that her motivation arises from the pain of rejection and her desire to leave her father's restrictive house. The narrator says of Maria, "In all the important preparations of the mind she was complete; being prepared for matrimony by an (sic) hatred of home, restraint, and tranquility; by the misery of disappointed affection, and contempt of the man she was to marry." 22 Sir Thomas, trapped by his perspective that privileges his estate and reputation, "was satisfied; too glad to be satisfied perhaps to urge the matter quite so far as his judgment might have dictated to others ... [,] happy to secure a marriage which would bring him an addition of respectability and influence." ${ }^{23}$ Because of his own worldview and his selfishness, Sir Thomas only increases the suffering to come as Maria will eventually marry Rushworth only to commit adultery in a public manner that brings consequences to the entire family. The narrator foreshadowed it for the reader, who, alas, knows Maria better than her father. Sir Thomas admits as much to himself after the deed when he realizes that he "had been governed by motives of selfishness and worldly wisdom."24

18. Chodron, No Time to Lose, 866.

19. Douglas R. Kenrick, Norman P. Li, and Jonathan Butner, "Dynamical Evolutionary Psychology: Individual Decision Rules and Emergent Social Norms," Psychological Review 110, no. 1 (2003): 3-28, 17.

20. Brian Boyd claims, "No one before Austen needed free indirect style as a ready technical resource, because no one before Austen paid such minute attention to the way we monitor ourselves and each other so finely" (22). Brian Boyd, "Jane Meet Charles: Literature, Evolution, and Human Nature," Philosophy and Literature 22 (1998): 1-30.

21. Austen, Mansfield Park, 156.

22. Austen, 158.

23. Austen, 157.

24. Austen, 362. 
The Bertrams and Crawfords, like most of us, according to Buddhism, continually wish to avoid suffering and pain, unlike the bodhisattva, who is open to any experience. Avoidance, though, only magnifies suffering. To use the same example of Maria marrying Rushworth, she has trapped herself by agreeing to the engagement, which is exemplified in the scene at Rushworth's estate, Sotherton, by the locked gate on the grounds. In that scene, Maria refuses to be shut in and temporarily escapes with her future lover, Henry Crawford. However, when Henry later leaves and no longer serves as the rescuer from the engagement she now regrets, Maria decides, "Henry Crawford had destroyed her happiness, but he should not know that he had done it; he should not destroy her credit, her appearance, her prosperity too." 25

Maria escapes through the gate but is still trapped by the mindset that marriage is her rescue and refuses to see how she must create her own happiness. Rather than face potential humiliation and prove to Henry that he has broken her heart, Maria avoids that suffering but makes her situation worse by marrying a man she dislikes. Ultimately, she in fact allows Henry Crawford to "destroy her credit, her appearance, her prosperity too." Maria must face some pain either before she marries Rushworth or after to truly escape her previous bad choice, but she creates greater suffering for herself and all around her. According to the Dalai Lama, Maria would be suffering from the "pervasive suffering of conditioning": unexamined thoughts and emotions that guide words and deeds. ${ }^{26}$ She lacks awareness due to the blindness of her perspective and her refusal to face how she has created her own suffering. ${ }^{27}$

Bodhisattvas do not create suffering or avoid it but rather let "the suffering of adversity soften them and make them kinder." ${ }^{28}$ Rather than running from life's suffering, a bodhisattva sits with it, looks deeply at it, and feels it fully. A bodhisattva is not a masochist who courts pain, but through not spending all energy avoiding pain, the bodhisattva can be fully present to the moment, to herself, and to those around her. ${ }^{29}$ Suffering can produce empathy, a powerful emotion capable of bringing great healing. According to Chodron, in "bodhicitta training, we learn to use whatever pain or fear we experience to open our hearts to other people's distress." ${ }^{30}$ A bodhisattva moves beyond concepts by cultivating the paramitas, which, literally translated, means "going to the other shore." The six paramitas are generosity, discipline, patience, enthusiasm, meditation, and wisdom.

Wisdom refers to understanding impermanence and emptiness. While the eighteenth century saw the rise of the individual and the associated rise of the novel, Buddhism argues that the individual conceived as a separate entity does not exist: it is a convenient fiction we tell ourselves to sustain our daily lives. Henry Aronson explains, "Our separate and independent existences are merely figures of speech: easy to recognize, identify, and name, but no more than temporary formations, composed of the same stuff." 31 To cling to an inflexible

\section{Austen, 158}

26. Dalai Lama, How to Practice: The Way to a Meaningful Life, ed. and trans. Jeffrey Hopkins (New York, Atria Books, 2002), 9.

27. In No Time to Lose, Pema Chodron states, "Expecting lasting happiness from a shift in outer circumstances will always disappoint us" (735).

28. Chodron, No Time to Lose, 127.

29. Anne K. Mellor and Alex L. Wilson accuse Fanny of "intense masochism" (228). As an aspiring bodhisattva, Fanny does not court or enjoy pain; rather, she understands how to manage it and does not flee from the inevitable suffering in life. "Austen's Fanny Price, Grateful Negroes, and Stockholm Syndrome," Persuasions 34 (2012): 222-35.

30. Chodron, No Time to Lose, 200.

31. Harvey Aronson, Buddhist Practice on Western Ground: Reconciling Eastern Ideals and Western Psychology (Boston: Shambhala, 2004), 71. 
narrative of the self — a form of attachment — creates more suffering. However, we are very prone to doing so.

A Harvard study found that people generally acknowledged how much they had changed in the past but tended to grossly underestimate how much they will change in the future. The participants saw their current identity, no matter what their age, as a stable one, a sort of endgame that previous change had brought them to permanently. However, the evidence - their own reading of their own lives as filled with change - predicts that they will continue to change. ${ }^{32}$ The participants created a narrative of stable identity destined to create suffering because it will make them resistant to change as they cling to their rooted ideas of themselves. The Dalai Lama similarly states that our degree of anger or attachment is tied to "grasping onto a sense of self or the thought, 'I am.' At a gross level we tend to conceive the self as an entity independent of our body and mind, in the manner of a controller, possessing some kind of self-sufficient, autonomous reality. Grasping at this sense of self is quite instinctual." 33 In other words, instinct leads humans to create the identity of a stable self, which is why suffering is inevitable, for clinging to that idea leads to suffering.

Fanny, of course, shares Shantideva's outsider status, and her ability to endure and end suffering owes much to how her difficult life circumstances teach her how to handle suffering. Austen establishes the sources of Fanny's suffering before readers even meet her. Upon inviting her to live at Mansfield Park, Sir Thomas explicitly draws boundaries between Fanny and her cousins: "I should wish to see them very good friends, and would on no account, authorize in my girls the smallest degree of arrogance towards their relation; but still they cannot be equals. Their rank, fortune, rights, and expectations, will always be different. ${ }^{~}{ }^{34} \mathrm{He}$ thus undercuts the very premise of Buddhist enlightenment - the equality and interconnectedness of all — and gives license to Mrs. Norris to treat Fanny very differently from her other nieces. With mean spirit, Mrs. Norris does this from the moment Fanny arrives, lecturing her on ingratitude when she sees her understandable sadness at being separated from her immediate family, and assigning her to an attic room. We also learn that ten-year-old Fanny is "somewhat delicate and puny" and that Fanny's less-than-optimal health is a recurring issue throughout the novel. ${ }^{35}$ All of this makes her poor Fanny indeed compared to the Bertram sisters, raised in wealth and privilege.

However, Fanny's poor life circumstances create the conditions that awaken her bodhisattva nature as compared to her cozened cousins. The right relationship to suffering drives out pride, offering humility and making us less self-centered; it creates empathy, enabling us to relate to our fellow sufferers and feel connected with our human condition; it positions us to gain a greater understanding of cause and effect; and it creates the will to do good, inculcating the virtues rather than causing pain. ${ }^{36}$ In his instructions on how to awaken bodhicitta, Shantideva writes:

There's nothing that does not grow light

Through habit and familiarity.

Putting up with little cares

I'll train myself to bear with great adversity! (6:14)

32. Aronson, Buddhist Practice, 69-70.

33. Dalai Lama, Practicing Wisdom: The Perfection of Shantideva's Bodhisattva Way, ed. Thupten Jinpa (Somerville, MA: Wisdom Publications, 2004), 55.

34. Austen, 9.

35. Austen, 9.

36. Chodron, No Time to Lose, 627-29. 
Fanny's lifelong challenges that come from her outsider status and frail health teach her how to endure " little cares" so that she is better able "to bear with great adversity." The deprivations created by Mrs. Norris, such as no fire in the East room or the long walks to fetch things for her that tax Fanny's strength, make it possible for Fanny to sit comfortably with her suffering, unlike her cousins. Pema Chodron notes that there "is no practice more important than relating honestly and sanely with the irritations that plague us in everyday life."37

The relative isolation due to her social status also teaches Fanny to be comfortable with being alone and undistracted from what is happening in the present moment, good or bad. When on the road to Sotherton, she "was not often invited to join in the conversation of the others, nor did she desire it. Her own thoughts and reflections were habitually her best companions." ${ }^{38}$ Fanny wastes no energy on forcing her way into a conversation or on bitterness about not being included; rather, she uses this opportunity to cultivate the self-reflection that leads to self-understanding and which is not available to any other characters in the novel. ${ }^{39}$

We see the contrast repeatedly and early. For example, when Fanny sits abandoned in the ha-ha at Sotherton, Julia, who has also been left behind by the young people, finds her and takes out her bad temper on Fanny, saying, "Such a penance as I have been enduring, while you were sitting here so composed and so happy! It might have been as well, perhaps, if you had been in my place, but you always contrive to keep out of these scrapes." Fanny, of course, rarely gets her own way and almost always is at the beck and call of her aunts, so the charge is completely unfair. But it is precisely being unable to get her way that benefits Fanny here. With a lifetime of living at others' whims, Fanny knows better than to overreact to Julia's rude comment. She refuses to increase suffering through a story that increases her victimhood. In addition, Fanny at this moment is far from happy, which Julia fails to notice entirely. Fanny bears the attack with patience: "This was a most unjust reflection, but Fanny could allow for it, and let it pass; Julia was vexed, and her temper was hasty, but she felt that it would not last." 40 Unlike her cousin, Fanny reads Julia correctly and also makes allowances for her, as she has observed already that Julia is unsuccessfully competing with her sister for status and male attention. She recognizes Julia's mood as impermanent and thus not something to fixate on.

Austen directly links Maria's and Julia's bad choices to the endless flattery and favoritism given to them by their Aunt Norris, noting that Julia's less-harmful choices come from being "less the darling of that very aunt" causing her "to think herself a little inferior to Maria" so that "her education had not given her so very hurtful a degree of self-consequence." Maria, the cousin who suffers least growing up, consequently, causes the most suffering for everyone. Austen even lays some of the blame on Maria for Julia's elopement, telling the reader, "She had not eloped with any worse feelings than those of selfish alarm. It had appeared to her the only thing to be done. Maria's guilt had induced Julia's folly."41 Constant praise has made them selfish. Shantideva addresses the problems with praise:

\section{Veneration, praise, and fame}

37. Chodron, No Time to Lose, 725.

38. Austen, 64.

39. Dawn Potter believes that "among all the major characters in Mansfield

Park, [Fanny] is the only one who studies her own personality." Dawn Potter, "In Defense of Dullness or Why Fanny Price Is My Favorite Austen Heroine," Sewanee Review 116, no. 4 (2008): 611-18, 612. Pema Chodron notes that such powers of self-reflection are essential for enlightenment: "In all kinds of situations, we can find out what is true simply by studying ourselves in every nook and cranny" (When Things Fall Apart, 149).

40. Austen, 80.

41. Austen, 366. 
Serve not to increase merit or my span of life

Bestowing neither health nor strength

And nothing for the body's ease. (6:90)

Praise brings no benefit. Yet praise has been the mainstay of the Bertram girls' education, and it has left them vulnerable to envy and to the flattery of Henry Crawford. In this way, Mrs. Norris has done more harm to her favorite nieces than to Fanny in spite of her unkind treatment, for "troublemakers" require an "exercise of patience" that purifies the tormented; the tormenter creates a personal hell for herself. ${ }^{42}$ This is certainly true of Fanny and Mrs. Norris by the novel's end, with Fanny's patience producing happiness and Mrs. Norris in a hell of her own making with Maria. Perhaps this explains Fanny's seeming "almost as fearful of notice and praise as other women were of neglect." 43

In addition to differences in how they are treated within the family, the Bertram sisters and Mary Crawford experience strong health compared to Fanny. Buddhism does not vilify the body. Importantly, the Buddha rejected the extreme asceticism he had undergone as part of his quest for enlightenment, recognizing its failure and advocating instead for a more balanced approach - the Middle Way. The problem is not the body per se but our attachment to the body since the "body has its place and value, but the mind must be freed from an obsessive and enslaving preoccupation with it." 44 Such preoccupation can lead to not distinguishing between happiness and pleasure. Shantideva writes:

All the joy the world contains

Has come through wishing happiness for others.

All the misery the world contains

Has come through wanting pleasure for oneself. (8:12)

Happiness can be achieved without sensual pleasure, and sensual pleasure can come at the cost of happiness, for the temporarily pleasant bodily sensation may come at an emotional cost or at the expense of integrity. The problem is attachment or, in Tibetan, shenpa. Dzigar Kongtrul describes attachment as "the 'charge' behind emotions: the charge behind 'I like and don't like,' the charge behind self-importance itself." 45 The focus on one's own comfort and pleasure undercuts the ability to care for others and empathize with them. It leads to egocentrism as we seek to avoid those things we don't like and to cling to those we do.

Mansfield Park's best example of pleasure-seeking egocentrism is Mary Crawford, particularly in the scene in which she keeps Fanny's horse well into Fanny's scheduled riding time. "Active and fearless ... [and] strongly made," Mary finds "pure genuine pleasure" in the exercise. ${ }^{46}$ She assures Edmund that the long ride has not tired her in the least. "I am very strong," she tells him. "Nothing ever fatigues me, but doing what I do not like," she says and then wishes Fanny a "pleasant ride." Edmund, when asking Fanny when he might next offer the horse to Mary, notes, "She rides only for pleasure, you for health." ${ }^{47}$ Mary later claims that "resting fatigues me." 48

42. Chodron, No Time to Lose, 751.

43. Austen, 155.

44. "Introduction," The Way of the Bodhisattva, 12.

45. Qtd. in Chodron, No Time to Lose, 257-58.

46. Austen, 53.

47. Austen, 55.

48. Austen, 76. 
Mary's constant desire for pleasure and activity leads directly to her selfishness, both keeping the horse from Fanny, whose health consequently suffers, and in leaving Fanny behind at Sotherton when she ventures off with Edmund. Though sounding ironic, Miss Crawford admits as much in her apology to Fanny when returning her horse: "I have nothing to say for myself-I knew it was very late, and that I was behaving extremely ill; and, therefore, if you please, you must forgive me. Selfishness must always be forgiven you know, because there is no hope of a cure." 49 But, of course, the practice of a bodhisattva is exactly the cure for selfishness. Seduced by her pleasurable company, Edmund also becomes short-sighted and selfish, for in his efforts to please Mary, he forgets Fanny. Again, there is nothing wrong with activity - with riding or walking — other than it leading to egocentric pleasure in one's own bodily activity and thereby to lack of empathy for others.

This becomes yet more exaggerated with the one completely unlikeable character of the novel: Mrs. Norris. While Mary's active, witty nature that veers into occasional indiscretion may be excused and even admired by some, Mrs. Norris is so universally disliked that J. K. Rowling named Argus Filch's spying cat after her. As with Mary Crawford, Austen immediately describes Mrs. Norris as having "a spirit of activity" that stems from ego. ${ }^{50}$ She exemplifies "the three main bases of self-importance: attachment to possessions, body, and merit" with her obsessive parsimoniousness, her pride in her physical endurance, and her need to call attention to all of her acts of merit. ${ }^{51}$ Examples abound, but one that will do is her response to Sir Thomas's return from the West Indies:

She was vexed by the manner of his return. It had left her nothing to do. Instead of being sent for out of the room, and seeing him first, and having to spread the happy news through the house, Sir Thomas, with a very reasonable dependence perhaps on the nerves of his wife and children, had sought no confidant but the butler, and had been following him almost instantaneously into the drawing-room. Mrs. Norris felt herself defrauded of an office on which she had always depended, whether his arrival or his death were to be the thing unfolded; and was now trying to be in a bustle without having any thing to bustle about, and labouring to be important where nothing was wanted but tranquility and silence. ${ }^{52}$

Austen's narrator makes clear that Sir Thomas's safe arrival home or death makes no difference to Mrs. Norris. What matters is her own active importance in the event. She is active and lacks all empathy. She is purely selfish, interested only in the appearance of doing good. When Sir Thomas gently confronts Mrs. Norris with the impropriety of the playacting in his absence, she defends herself by praising her "general attention to the interest and comfort of his family, much exertion and many sacrifices to glance at in the form of hurried walks and sudden removals from her own fireside" and, most importantly, her "active" matchmaking that brought about the engagement of Maria to Mr. Rushworth (an activity that results in disaster). ${ }^{53}$ Tanner is right in saying that "all the characters who go wrong share a distaste for "tranquility"' and that the novel prefers rest over motion. ${ }^{54}$

49. Austen, 54.

50. Austen, 4.

51. Chodron, No Time to Lose, 257.

52. Austen, 141.

53. Austen, 148.

54. Tanner, Jane Austen, 153. 
Certainly, Austen is not rejecting activity completely, nor is she endorsing indolence, for Lady Bertram is no model. Rather, Buddha-like, we have an endorsement of a middle way of "thoughtful rest" while rejecting "the dangers of thoughtless restlessness." 55 Fanny's isolation and lack of endurance create opportunities for her to live comfortably with her own thoughts and company, so she has learned the art of the pause. Rather than responding immediately to what is happening around her, she has developed powers of observation and the ability to refrain from merely responding or reacting impulsively. When she begins to feel envy after Edmund agrees to act in Lovers' Vows, "reflection brought better feelings." 56 When she becomes anxious about the rehearsal where Mary Crawford and Edmund will perform their parts together, she honors "her wish to retreat, and she worked and meditated in the East room." ${ }^{57}$ When speaking to Edmund about how Mary can't understand why she won't accept Henry's proposal, she responds only "after a pause of recollection and exertion." ${ }^{58}$ While readers and critics have complained of Fanny's passivity and seen her quiet acceptance in such examples as defeatism, her ability to withdraw and respond with calm detachment indicates an aspirant moving toward enlightenment.

The contrast between Fanny's "thoughtful rest" and Mary's "thoughtless restlessness" appears when the two sit together in Mrs. Grant's shrubbery. Austen guides the reader in how to interpret the interaction by explaining that it as "an intimacy resulting principally from Miss Crawford's desire of something new." ${ }^{\circ 9}$ Even an attempt at friendship comes from Mary's restlessness. As the women sit together, Fanny, struck by the beauty of her natural surroundings, verbalizes her admiration and philosophizes, while Miss Crawford, "untouched and inattentive, had nothing to say." ${ }^{60}$ Fanny, after a pause, once again admires the scene, explaining, "When I am out of doors, especially when I am sitting out of doors, I am very apt to get into this sort of wondering strain." Mary responds, "I see no wonder in this shrubbery equal to seeing myself in it." ${ }^{61}$ She then quickly follows up with snide, materialistic comments about the Rushworths. Whereas Fanny demonstrates a sense of connection, Mary concentrates on herself as an individual, and her comments about the Rushworths show her solipsism and lack of empathy. The conversation demonstrates Fanny's ability to be in the moment and value it, whereas Mary relapses "into thoughtfulness," unable to appreciate her surroundings, preferring her own thoughts, her own narrative of a possible future with Edmund - if he changes as she directs.

To reinforce the value of being still in a thoughtful manner, Austen gives her readers Tom Bertram. Tom spends most of the novel as the disappointing, profligate older son whose expenses cost Edmund the living that must now go to Dr. Grant. When Sir Thomas confronts him with this, "Tom listened with some shame and some sorrow; but escaping as quickly as possible, could soon with cheerful selfishness reflect" on a list of excuses. ${ }^{62}$ We see Tom escaping his father, his responsibility, and his appropriate feelings of shame and sorrow in order to immediately revert to his selfish nature. The verb reflect is truly ironic. Through costing the living for Edmund, Tom is indirectly responsible for introducing the catalyst to the Bertrams' woes in the form of the Crawfords. In addition, he directly introduces theatricals to Mansfield Park during Sir Thomas's absence, which leads to further chaos and opportunities

55. Tanner, Jane Austen, 173.

56. Austen, 125.

57. Austen, 132.

58. Austen, 277.

59. Austen, 162.

60. Austen, 163.

61. Austen, 164.

62. Austen, 19. 
for Henry to seduce Maria. But Tom's illness changes him; he regains his health "without regaining the thoughtlessness and selfishness of his previous habits. He was the better for ever for his illness. He had suffered, and he had learnt to think, two advantages he had never known before." ${ }^{\prime 63}$ Like Shantideva, Austen here links suffering to the ability to pause and think and labels suffering itself as an advantage. Shantideva concurs:

The cause of happiness is rare,

And many are the seeds of suffering!

But if I have no pain, I'll never long for freedom. (6:12)

Pain, suffering, and illness have value as motivation to achieve spiritual freedom.

Fanny's freedom comes from her liminal status, which prevents her from being caught by concepts, unlike the other characters who are pigeonholed into their various roles. Mary Crawford expresses confusion over Fanny's status, asking "Is she out, or is she not? I am puzzled.- She dined at the parsonage, with the rest of you, which seemed like being out; and yet she says so little, that I can hardly suppose she is." ${ }^{64}$ A discussion follows between Mary and Tom about the usually clear distinctions between "in" and "out" and how awful it is when such decorum is violated. Fanny, however, is neither in nor out. The distinction that Sir Thomas draws so early, and that is so carefully reinforced by Mrs. Norris, remains firm until Sir Thomas returns from the West Indies. Even then, Fanny is not recognized as a rightful, full member of the family until after Maria's adultery, so she is never forced to deal with the trials of being in or out. She escapes the kind of damage inflicted upon the Bertram sisters by their education as proper ladies, one that traps them by a society that carves out narrow limits for their lives. Fanny lives a life without expectations and is surprised, for example, when she realizes she is to lead the ball as Sir Thomas's niece. Rather than seeing the ball as part of the machinations of matchmaking that it is, Fanny is free to see it as a dance, and while she feels self-conscious as a young woman not used to public appearances, she does not see herself as being on display as a possible mate. This liminality is a hallmark of the bodhisattva. The Dalai Lama describes the bodhisattva as being in an in-between state as she does not enter nirvana or "solitary peace" but chooses cyclical existence out of a sense of altruism. ${ }^{65}$ She is enlightened without opting for the award of enlightenment, which is an escape from this world's suffering.

Unlike Fanny, for the other residents of Mansfield Park, ideas about a stable self are burdened with expectations and definitions of what is expected of a lady or a gentleman. This is in contrast with the Buddhist path to happiness, which involves dropping "our ideals of who we think we ought to be, or who we think we want to be, or who we think other people think we want to be or ought to be." ${ }^{, 66}$ All of the Bertram children attempt escape: Maria and Julia via men; Tom via his profligate lifestyle; and even Edmund, temporarily, via acting in the play (even though he does so for "noble" reasons). Because they cannot escape the roles thrust upon them by their social positions, the ladies and gentleman take on different roles via Lovers' Vows.

However, adopting a role is a pleasurable escape, not a true path to happiness, and the playacting exemplifies each character at his or her most selfish, which we can see from the moment the idea is proposed. Mr. Yates, in introducing the idea, is filled with self-pity that playacting had been canceled due to a death in the family. Mr. Yates expresses his desire that

63. Austen, 363.

64. Austen, 39.

65. Dalai Lama, Practicing Wisdom, 83.

66. Chodron, When Things Fall Apart, 120. 
the death could have been ignored a few days so that the play could proceed, it "being only a grandmother, and all that happening two hundred miles off." ${ }^{97}$ From this ignominious start, the play produces only problems. Those who act in it (or wished to in Julia's case) are unkind, unobservant, angry, and/or jealous. Fanny, who avoids prescribed, predetermined roles in life, refuses to act and, thereby, escapes the dangers of the play's narrative.

We can see this most clearly in comparing Julia and Fanny as "two solitary sufferers," each feeling jealousy but experiencing it in such a different manner. Julia loses her preferred role to her sister and must watch her act intimate scenes with the man they both desire, Henry Crawford. Julia responds by refusing to participate, which might be a good solution, but she finds no peace, for "her heart was sore and angry, and she was capable only of angry consolations." ${ }^{68}$ She makes "no endeavour at rational tranquility for herself." ${ }^{69}$ While Julia removes herself physically from the play, she stays mired in the scene of suffering, nurturing anger rather than seeking peace. Only Fanny sees this. Those around Julia are, to return to the metaphor from Pema Chodron's commentary on The Way of the Bodhisattva, full pots: "The inattention of the two brothers and the aunt to Julia's discomposure, and their blindness to its true cause, must be imputed to the fulness of their own minds. They were totally pre-occupied."70 In other words, other than Fanny, Julia is surrounded by self-centered and selfish people.

Fanny, on the other hand, is a witness to all and perceives everyone correctly because she is not caught by jealousy or any given role. She realizes that "far from being all satisfied and all enjoying, she found every body requiring something they had not, and giving occasion of discontent to the others." Her conclusions come not just from observation, however, but because everyone turns to her with their problems. Fanny enacts in the Lovers' Vows rehearsals the eightfold path. Deep listening is the foundation for Right Speech, and "Fanny, being always a very courteous listener, and often the only listener at hand, came in for the complaints and distresses of most of them." 71 Thanks to her liminal status, she engages in Right View and Right Thinking — correct perception not marred by concepts - throughout the novel. As explored previously, Fanny continues to use Right Mindfulness, looking within to understand the cause of her suffering. When Edmund accepts a role in the play after protesting about how wrong it is to act, she finds that "her indifference to the danger was beginning to fail her," that she "was at first in some danger of" envy, and that she is "agitated" and "anxious." 72 Unlike Julia, Fanny sits with her suffering, examines it, and is then free from it, finding peace, which she achieves via Right Diligence - that is, applying herself earnestly to the endeavor with good intent. Lastly, she shows Right Concentration, not escaping as everyone else is but staying present, which allows her to see the suffering of all, and engages in Right Livelihood, offering her time and service with compassion, for example, memorizing Mr. Rushworth's lines in an effort to help him "in her pity and kind-heartedness."73 In this way, while the others seek pleasure, Fanny continues to offer happiness, defined by Thich Nhat Hanh as benefiting and nourishing everyone. ${ }^{74}$

Those characters who do enjoy the play perform as directors and actors in their everyday lives. Mrs. Norris happily participates behind the scenes, oblivious to any impropriety and certainly unworried about Sir Thomas's wishes. Long before the play, Austen describes

67. Austen, 97.

68. Austen, 127.

69. Austen, 125.

70. Austen, 128.

71. Austen, 129.

72. Austen, 124, 125, 131.

73. Austen, 130.

74. Thich Nhat Hanh, Heart of the Buddha's Teaching, 78. 
Mrs. Norris in rather theatrical terms, referring to "her love of directing." 75 Henry Crawford is by far the best actor, which gives insight into someone who lives a part rather than reflecting on his own character. Fanny is "the only one of the party who found any thing to dislike" in Henry. ${ }^{76}$ But the narrator assures us that she is quite correct, telling the reader that Henry lacks "the habit of examining his own motives, and reflecting to what the indulgence of his idle vanity was tending; but, thoughtless and selfish from prosperity and bad example," Henry knowingly plays games with Maria and Julia, just as he will attempt to do later with Fanny. ${ }^{77} \mathrm{He}$ does so via the overt acting of scenes but also through staging them, for example, reading the Shakespeare play aloud, performing conversations for Fanny's benefit, insisting on helping during the card game at the Grants', and having Mary offer Fanny a chain for her pendant to trick her into accepting a gift and thereby be in his debt. Penny Gay points to the necklace scene as support that "Mary is adept at improvising scenes which utilise her seductive powers." 78 Gay sees this as just one example of how Mary acts and directs scenes in order to manipulate those around her. These characters who are acting scripts are caught by narrative, unlike Fanny, the constant observer who sees "all that was passing before her."79

Because Fanny operates in the moment, responding to her circumstances with flexibility, and engaging in self-reflection, the charge that she is a self-righteous prig is wrong. And rather than being a sadomasochistic victim, as some charge, Fanny exhibits humility and, in a quiet way, self-confidence by the end of the novel. Faced with the bullying and intimidating Sir Thomas calling her ungrateful and selfish in her refusal of Henry Crawford, Fanny stands her ground, knowing that she and Henry could not make each other happy. Certainly, the argument exists that it is her love for Edmund that prevents her acquiescence to the engagement rather than internal conviction, but Fanny is also clear in knowing that Edmund wants Mary, not her. Her refusal comes at great cost to herself and to her family, whom Henry could help with his funds. It comes from a sense of what is right, not hope for a future with Edmund. It is also true that Fanny begins to see Henry in a more positive light when in Portsmouth, which serves only as a refutation of those critics who argue that Fanny is boorish in being always and only right. Rather, Fanny struggles throughout the novel, as any aspirant would, in facing difficult emotions. And she does continue to resist the seductive Crawfords, refusing their offer to return her to Mansfield and choosing to remain with her family even as it harms her health. Instead, she turns her bodhisattva nature to good use, resolving disputes and helping Susan.

None of this makes Fanny unique. Buddhists believe that everyone has Buddha nature within, and anyone who chooses to awaken bodhicitta and achieve enlightenment out of altruism can become a bodhisattva. Fanny is fortunate in the life circumstances that offer her freedom not available to the other characters. Julia, Maria, and Mary are educated in how to be proper young ladies, an education that ultimately traps them not just socially but also conceptually; they psychologically limit themselves. Mrs. Norris addresses Sir Thomas's concerns about bringing Fanny to Mansfield Park by saying, "Give a girl an education, and introduce her properly into the world, and ten to one but she has the means of settling well." ${ }^{80} \mathrm{Ed}$ ucation for proper ladies, as Mary Wollstonecraft argued in A Vindication of the Rights of Woman only twenty-two years earlier, did more harm than good, training them only to catch

75. Austen, 7.

76. Austen, 92.

77. Austen, 91.

78. Gay, Jane Austen and the Theatre, 114.

79. Austen, 145.

80. Austen, 5 . 
husbands. Sir Thomas echoes these thoughts in lamenting the education of his daughters, deciding "they had never been properly taught to govern their inclinations and tempers," for he "had meant them to be good," but "that with all the cost and care of an anxious and expensive education," his daughters had learned ladies' manners only. ${ }^{81}$

Similarly, though Edmund is guilty of looking for ways to excuse Mary's behavior when smitten with her, he is not wrong in blaming her thoughtlessness on a poor education and poor role models. While some critics see Fanny as Edmund's mere cipher-he takes charge of her education - she benefits greatly from her deep reading and his guidance. Shantideva argues for the importance of teachers, and while Edmund's infatuation with Mary blinds him for a while, he is still an excellent model of many attributes of enlightenment. For example, he is the only member of the Bertram family to see Fanny's distress upon moving to Mansfield Park, offering deep listening and compassion. ${ }^{82}$ Most importantly, Fanny as student clearly surpasses Edmund as teacher with her clarity of vision and self-discipline.

In their article "A History of the Fanny Wars," Troost and Greenfield reference an August 2014 Los Angeles Review of Books piece by Anna Keesey, who describes her movement from dislike of Fanny as "Anglican doormat" to an appreciation of her as "a hero on a winged horse," offering with her "stillness" an antidote for our times in which "rough beasts are aslouch on the road to many Bethlehems." ${ }^{83}$ Perhaps our modern pieties have changed so that Fanny and Mansfield Park no longer offend. Within the last few years Robert Wright's Why Buddhism Is True was ranked No. 4 on the New York Times bestseller list and Time's 2017 special issue was devoted to mindfulness. We may now be at a cultural moment in which our own perspectives have shifted in such a way that we can see Fanny Price anew and appreciate her bodhisattva nature. We might even have something to learn from her about cultivating a bit of bodhicitta ourselves.

81. Austen, 364

82. Jane McDonnell notes that Edmund is the only character in Mansfield Park to foster Fanny's intellectual growth and to esteem her sensitivity and "spirituality." Jane McDonnell, "“A Little Spirit of Independence:' Sexual Politics and the Bildungsroman in Mansfield Park," Novel 17, no. 3 (1984): 197-214. For another defense of Edmund's education of Fanny, see Marija Reiff, “The 'Fanny Price Wars': Jane Austen's Enlightenment Feminist and Mary Wollstonecraft,” Women's Studies 45 (2016): 275-90.

83. Qtd. in Troost and Greenfield, History of the Fanny Wars, 29. 